\title{
Improving the Quality of Coconut Cream-based Pasta Through the Presence of Sago Starch and Surfactants: Application as an Ingredient of Rendang Seasoning
}

\author{
Anggita Nugrahanto ${ }^{1}$, Sutardi $^{1 *}$, Umar Santoso $^{1}$
}

\author{
1)Department of Food and Agricultural Product Technology, Faculty of Agricultural Technology, \\ Gadjah Mada University, Yogyakarta, Indonesia \\ *) Correspondence Email: sutardi@ugm.ac.id
}

\begin{abstract}
Coconut processed products (coconut cream) are widely used in the food field. However, various ways, such as adding starch and surfactants, still need to be made to improve the stability of coconut cream. This study aimed to evaluate the addition of starch and surfactant on the stability of coconut cream and its use as an ingredient of rendang seasoning. The separation of coconut milk into coconut cream was conducted using the cold $(4 \mathrm{oC}$ for \pm 18 hours) and cream separator method. After that, Hydrophilic-Lipophilic Balance (HLB) 5 (1\%) surfactant and sago starch (3\% and 5\%) were added to the coconut cream to produce a coconut cream paste, which was later used as an ingredient in the rendang seasoning. The quality parameters of coconut cream such as zeta potential, viscosity, free fatty acid content were evaluated in this study. The results showed that the cream separator method with $1 \%$ surfactant HLB 5 and $3 \%$ sago starch improved the coconut cream paste stability with a zeta potential of $-30.5 \mathrm{mV}$ and free fatty acid of $0.1 \%$. This method was suitable for use as an ingredient of rendang seasoning indicated by a viscosity of $699.9 \mathrm{cPs}$, lightness of 32.51 , and $\mathrm{pH}$ of 4.41 . Therefore, the cream separator method could improve the coconut cream stability and be applied to rendang seasoning.
\end{abstract}

Keywords: coconut cream, cream separator, cold method, sago starch, rendang seasoning

\section{INTRODUCTION}

Coconut cream is a product that is easy to handle because of its thick, paste-like properties (Sasilika and Hasker, 2013). Coconut cream is widely used in the food field such as sapal (Gubag, 1996), gouda cheese (Mangalika et al, 2005), chocolate products (Divya, 2017; Jin et al, 2017), ice cream (Igutti et al, 2011; Aparecida et al, 2011; Aboulfazli et al, 2016), and aroma source (Shan et al, 2011; Sun et al, 2012). Coconut cream can also be applied to rendang (Azima and Sayuti, 2016). In fact, rendang is one of Indonesia's traditional food that contains several ingredients such as meat, coconut milk, seasoning, and herbs (Nurmufida et al, 2017). According to a survey from Cable News Network (2017), rendang is one of the world's tastiest and most favorite foods.

Several methods have been applied to obtain coconut cream, namely the cold method, the centrifugation method (Mangalika, 2004), and the cream separator method (Yin et al, 2015). Unfortunately, coconut cream is usually less stable during storage because of its unstable nature at room temperature (Arachchi et al, 2016). To date, few studies have studied the efforts to maintain the stability of coconut cream. The study of adding starch and surfactant product to improve coconut cream stability is still rare.

The addition of surfactants is considered to maintain the stability of a coconut-based emulsion. Several studies have evaluated the stability of coconut milk through the addition of surfactants such as sodium dodecyl sulfate (SDS) (Tangsuphoom and Coupland, 2009) and sucrose ester (Ariyaprakai et al., 2013). However, the addition of surfactants to coconut cream is still rarely reported, so that it needs to be studied further to maintain the stability of the coconut cream.

Emulsion stability can also be maintained by increasing the viscosity. Theoretically, high emulsion viscosity will slow down the fusion rate between droplets so that the emulsion remains stable according to Stokes law (McClements and Gumus, 2016). Gelatinized starch products are known to increase the viscosity of the emulsion. Wijayanti et al. (2015) stated that high amylopectin content in sago starch could form layers like strands and produce high viscosity when heated. Therefore, this study aimed to evaluate the addition of surfactants and sago starch on the stability of coconut cream and its application as an ingredient of rendang seasoning.

\section{MATERIALS AND METHODS}

\section{Materials}

Coconut was obtained from the Kebumen area, Central Java. Span 80 and Tween 80 (Merck KGaA, Germany). Sago starch was obtained from Merapi (PT Pondasi Intii Sejahtera, Indonesia). Rendang seasoning (instant pasta) was purchased from Indofood (Indonesia).

\section{Extraction of coconut milk}

The coconut flesh was minced and squeezed (the ratio of pulp and water is 2:1) using a traditional press machine. The coconut milk was then filtered using a coconut milk filter to produce coconut milk free of grated coconut.

\section{Production of coconut cream}

There are two methods used to produce coconut cream: the cold method and the cream separator method Hagenmaier (1980). Initially, coconut milk was pasteurized at $60^{\circ} \mathrm{C}$ for 15 minutes in waterbath (Julabo, Germany). In the cold method, coconut milk was stored at $4^{\circ} \mathrm{C}$ for 18 hours to form two fractions, a solid fraction (coconut cream) and a liquid fraction (skimmed coconut milk). In the separator cream method, the coconut milk was fed to a cream separator (GYRO TEST 353040-405 De Laval, USA). The coconut milk was separated into the cream and skim fractions just after feeding (about 30 seconds). From both methods, the cream fraction was taken to be evaluated and made into a paste form. The cream was stored at $4^{\circ} \mathrm{C}$ 


\section{Characterization of coconut cream Yield and proximate analysis}

The yield of coconut cream was obtained from coconut cream obtained (in grams) per one liter of coconut milk (Mangalika, 2004). The fat and protein content of coconut cream was analyzed using the AOAC method (2005). Moisture content analysis using a Moisture Content Analyzer (Ohaus, USA).

\section{Total amino acids profile}

Coconut cream's total amino acid profile identified using LCMS (Liquid Chromatography-Mass Spectrofotometry), XEVO TQD, Waters, USA. Initially coconut cream was hydrolyzed with $\mathrm{HCl} 6 \mathrm{~N}\left(20 \mathrm{~mL}\right.$ at $\left.110^{\circ} \mathrm{C}\right)$ for 12 hours. Then $\mathrm{NaOH} 6 \mathrm{~N}$ was used to neutralize the coconut cream-HCl mixture (up to a volume of $50 \mathrm{~mL}$ ). After that, the sample was filtered using a filter of $0.22 \mu \mathrm{m}$ and followed by dilution 25 times. Then $2 \mu \mathrm{L}$ of the sample was injected into LCMS instrument. Data were tabulated and evaluated by Masslynx V4.1.

The mobile phase used was A: $0.1 \%$ Pentadecafluorooctanoic Acid (PDFOA) 99.5\%: 0.5\% Water / $\mathrm{CH} 3 \mathrm{CN}$ with $0.1 \%$ Formic acid, B: $0.1 \%$ PDFOA, $10 \%$ : $90 \%$ Water $/ \mathrm{CH} 3 \mathrm{CN}$ with $0.1 \%$ Formic acid, with a flow rate of $0.6 \mathrm{~mL} /$ minute. The separation process was carried out through an eluent gradient. The composition of the mobile phase composition was as follows: component A (90\%) and component B (10\%) were eluted up to 5 minutes. Then, component $\mathrm{A}$ and component $\mathrm{B}$ were changed to $50 \%$ and $50 \%$ respectively for 12 seconds, then the composition was changed as before, namely $90 \%$ (A) and 10\% (B) until the 7 minutes. The separation was conducted in $\mathrm{C} 18$ column $(2.1 \mathrm{x}$ $50 \mathrm{~mm}$ ).

\section{Fatty acids profile}

The fatty acid profile of coconut cream was identified using GC-FID (Gas Chromatography-Flame Ionization Detector) (GC Agilent Technologies 7890B Standard Supelco 37 mix fame USA). The standard supelco $37 \mathrm{mix}$ fame mainly consist of methyl ester form of butyric acid (C4), valeric acid (C5), hexanoic acid (C6), octanoic acid (C8), capric acid (C10), lauric acid (C12), myristic acid (C14), palmitic acid (C16), stearic acid (C18), arachidonic acid (C20), behenic acid (C22), tetracosanoic acid (C24). The sample (1 $\mu \mathrm{L})$ and standart mix fame $(1 \mu \mathrm{L})$ were injected into GC (Shimadzu 2010, Japan) as described by Wihenti (2020) The column used was HP-88 (internal diameter $=0.25 \mathrm{~mm}$; film thickness $0.2 \mu \mathrm{m}$ ) with a length of 100 meters, the oven temperature used was $290^{\circ} \mathrm{C}$ with isothermal method and then detected by Flame Ionization Detector at $260^{\circ} \mathrm{C}$. The mobile gas used was Helium. Fatty acids profile can be detected based on comparation between retention time of chromatogram of sample with retention time of chromatogram of Standard mix Fatty Acid Methyl Ester (FAME).

\section{Preparation of mixed surfactant}

In this study, the HLB 5 surfactant was used to manufacture coconut cream. Tween 80 (HLB 15) and Span 80 (HLB 4.3) were used as the base material to prepare surfactants HLB 5. Briefly, 7\% (v/v) Tween 80 was mixed with 93\% (v/v) Span 80 manually for 1 minute at room temperature.

\section{Preparation of coconut cream paste}

The coconut cream paste was prepared by adopting Charoenkul and Darinee (2017) with major modifications. Initially, $70 \mathrm{~mL}$ of coconut cream was mixed with $29.99 \mathrm{~mL}$ of suspension of a sago starch (3\% and 5\%). Then $0.01 \mathrm{~mL}$ of
HLB 5 surfactant (mixture of Span 80 and Tween 80) was dropped in a mixture of coconut milk-starch cream. The mixture was then homogenized at a speed of $10000 \mathrm{rpm}$ for 5 minutes (Ultra Turrax T50, IKA WERKE Germany) to form a coconut cream paste. The manufacture of pasta without sago starch was also used as a comparison.

\section{Characterization of coconut cream paste \\ Creaming index}

The creaming index analysis was carried out by placing $50 \mathrm{~mL}$ of the sample in a glass bottle and followed by storing at $25 \mathrm{oC}$ for 7 days. The paste was physically evaluated by calculating the creaming percentage. The creaming index $(\% \mathrm{CI})$ was calculated using the equation:

$\% \mathrm{CI}=(\mathrm{CC} / \mathrm{CT}) \times 100$

where $\mathrm{CC}$ describes the top layer height and $\mathrm{CT}$ as total paste height

\section{Appearance}

Appearance analysis was performed directly (photograph camera phone 13 Mega Pixels), to evaluate the physical appearance of the paste. To evaluate the oil globule's shape dispersed in the paste, coconut cream was also observed microscopically (Optilab, Olympus CX21LED, Japan) at day 0 (freshly prepared emulsion). Each sample took 3 times observation.

Lightness

Lightness analysis was performed using a Chromameter (Chromameter CR-400, Japan). The sample was placed in a round sample container, which was then measured by the sensor on the Chromameter. Lightness was measured based on the number of letter L printed on the screen.

\section{pH}

$\mathrm{pH}$ analysis was performed using a $\mathrm{pH}$ meter (Metller-Toledo, Switzerland). The sample was placed into a glass beaker then the $\mathrm{pH}$ meter probe was immersed in the sample. The $\mathrm{pH}$ value of the sample was obtained based on the numbers on the screen. Immersion in mixture of technical buffer solution with $\mathrm{pH}$ 4.01, $\mathrm{pH} 7$ and $\mathrm{pH} 9.21$ buffer (Metller-Toledo, Switzerland) was conducted before and after sample measurement.

\section{Viscosity}

Viscosity was measured using a viscometer (RVTD, USA). The sample was put into the container. Then the S64 spindle was immersed in the sample and run at $6 \mathrm{rpm}$ for 1 minute at room temperature. The viscosity value of the sample was obtained based on the numbers on the screen.

\section{Globules Properties}

Globule dispersed in the paste was evaluated for its character based on the mean particle size and zeta potential parameters using a Nanoparticle analyzer (Horiba SZ-100, England) (Le and Van, 2014).

\section{Free fatty acid (FFA) content}

Firstly, the coconut cream paste sample was mixed with hexane (4:1) because of high affinity of coconut cream oil in hexane. Afterward, the mixture was stirred until the oil phase of the paste dissolved in hexane. Hexane evaporation was carried out using a rotary vacuum evaporator (RV06-ML, IKA-WERKE, Germany) to separate n-hexane from the oil. Then the free fatty acid devaluation oil was based on the AOAC method (2005). 
$\%$ FFA $=\frac{\text { volume } \mathrm{NaOH} \times \text { Normality } \mathrm{NaOH} \times \text { Molecular weight of fatty acid }}{\text { Molecular weight } \times 1000} \times 100$

\section{Making Rendang Seasoning}

Briefly, the coconut cream paste $(30 \mathrm{~mL})$ was mixed with commercial rendang seasoning $(30 \mathrm{~g})$ for 5 minutes at $10000 \mathrm{rpm}$ (Ultra Turrax T50, Germany). Then, the rendang seasoning paste was left to stand for 24 hours at room temperature before being evaluated.

\section{Characterization of the rendang seasoning paste}

The rendang seasoning paste was evaluated by observing the parameters of viscosity, $\mathrm{pH}$, and lightness by the method described in 2.6. Commercial rendang seasoning paste was also evaluated for comparison.

\section{Data Analysis}

The coconut cream paste and the rendang seasoning were made in triplicate. The experiment design use a Randomized Complete Block Design. Data were tabulated using Microsoft Excel (Microsoft Inc, USA). Statistical evaluation of data using one-way ANOVA through SPSS v.20 software (SPSS, USA) with a significance level of $95 \%$ $(\mathrm{p}<0.05)$. The real difference test was carried out using DMRT (Duncan Multiple Range Test). Also, the comparison between the rendang-pasta seasoning mixture and the commercial rendang seasoning was analyzed using the independent sample t-test method with a significance level of $95 \%(\mathrm{p}<0.05)$.

\section{RESULT AND DISCUSSION}

\section{Characteristics of coconut cream}

The yield of coconut cream indicated the success rate of the coconut cream production method. The higher the yield, the higher the success rate of a method. The results showed that the coconut cream was $28 \%$ wt. using a cream separator (cream) and 68.66\% wt, using the cold method (cold cream) (Table 1). This occured because the centrifugal force of the cream separator makes the coconut milk separate according to its specific gravity, so that the coconut cream got fewer impurities (unwanted substances such as water, and protein). Hence the yield of the cream separator is lower than the cold cream.

Table 1. Characterization of coconut cream.

\begin{tabular}{ccc}
\hline & $\begin{array}{c}\text { Coconut Cream } \\
\text { Cream separator }\end{array}$ & $\begin{array}{c}\text { Coconut Cream } \\
\text { Cold Storage }\end{array}$ \\
\hline Yield $(\% \mathrm{wb})$ & $28.00 \pm 1.00^{\mathrm{a}}$ & $68.00 \pm 3.51^{\mathrm{b}}$ \\
\hline Fat $(\% \mathrm{wb})$ & $50.12 \pm 2.46^{\mathrm{a}}$ & $40.06 \pm 5.08^{\mathrm{b}}$ \\
\hline Protein $(\% \mathrm{wb})$ & $1.50 \pm 0.04^{\mathrm{a}}$ & $3.99 \pm 0.98^{\mathrm{b}}$ \\
\hline Moisture content $(\%)$ & $36.76 \pm 7.11^{\mathrm{a}}$ & $57.83 \pm 4.75^{\mathrm{b}}$ \\
\hline
\end{tabular}

Superscript letters that differ in one row indicate a significant difference in treatment $(\mathrm{p}<0.05)$ according to t-test, Values are expressed as mean \pm standard deviation

Meanwhile, coconut cream contained proximate content (fat, protein, moisture), which was different between the cream separator method and the cold method $(\mathrm{p}<0.05)$ (Table 1). This difference was thought to be related to differences in the principles between both methods. The centrifugal force in the separator cream method makes the oil separate optimally and produces a higher fat content than the cold method.

\section{Total amino acid profile of coconut cream}

Coconut cream contained amino acids dominated by glutamic acid, arginine, lysine, leucine, with concentrations ranging from 1082.25 to $3558.50 \mathrm{mg} / \mathrm{kg}$ coconut cream (Table 2). Amino acids obtained by the cold method were more abundant than the cream separator method. It happened because the cold method's protein content was more than the cream separator method (Mangalika, 2004). This finding was related to the higher protein content in the coconut cream from the cold method (Table 1).

Table 2. Total amino acid profile of coconut cream from both the cream separator and cold method as analyzed by using LCMS

\begin{tabular}{lcc}
\hline \multirow{2}{*}{ Amino acid } & $\begin{array}{c}\text { Coconut Cream } \\
\text { Cream separator }\end{array}$ & $\begin{array}{c}\text { Coconut Cream } \\
\text { Cold Storage }\end{array}$ \\
\cline { 2 - 3 } & content $(\mathrm{mg} / \mathrm{kg})$ & content $(\mathrm{mg} / \mathrm{kg})$ \\
\hline Glutamic acid & 2464.61 & 3558.50 \\
\hline Arginine & 1666.78 & 2956.95 \\
\hline Leucine & 1096.84 & 1669.42 \\
\hline Lycine & 1082.25 & 1253.68 \\
\hline Histidine & 991.95 & 898.91 \\
\hline Aspartic acid & 812.51 & 1378.63 \\
\hline Valine & 789.55 & 1265.30 \\
\hline Phenylalanine & 626.92 & 961.64 \\
\hline Glycine & 610.17 & 833.42 \\
\hline Alanine & 605.86 & 918.87 \\
\hline Proline & 538.58 & 783.31 \\
\hline Serine & 506.44 & 864.67 \\
\hline Isoleucine & 484.58 & 779.11 \\
\hline Threonine & 433.7 & 646.03 \\
\hline Tyrosine & 61.49 & 128.25 \\
\hline Cysteine & 21.43 & 35.04 \\
\hline Methionine & 4.35 & 243.19 \\
\hline
\end{tabular}

Glutamic acid, aspartic acid, alanine, glycine, proline, serine, tyrosine, and cysteinare are non-essential amino acids. Glutamic acid can provide an umami taste in food products (Yamaguchi and Ninomiya, 2000). While for arginine, histidine, is ole ucine, leucine, lycine, methionine, phenylalanine, threonine and valine is an essential amino acid. This amino acid can't be produced by the body so it must be obtained from outside the body. For example, by eating foods that contain these amino acids (Stryer, 1975).drinks during storage (Hemalata et al., 2018) and mix formulation of cape gooseberry, sweet lime, amla, and ginger (Lokesh and Sangma, 2017). 


\section{The Fatty Acid Profile of Coconut Cream}

Table 3 The fatty acid profile of coconut cream using GC-FID

\begin{tabular}{ccc}
\hline Fatty acid & $\begin{array}{r}\text { Coconut Cream } \\
\text { Cream separator } \\
\text { (\% relative area) }\end{array}$ & $\begin{array}{c}\text { Coconut Cream } \\
\text { Cold Storage } \\
\text { (\% relative area) }\end{array}$ \\
\hline Methyl Laurate & 48.64 & 47.90 \\
Methyl tetra-decanoate & 17.87 & 17.94 \\
Methyl palmitate & 8.76 & 9.02 \\
Methyl octanoate & 6.76 & 6.56 \\
Methyl decanoate & 6.22 & 6.06 \\
Methyl ester cis-9-oleate & 6.07 & 6.55 \\
Methyl ester trans-9-elaidic acid & 2.51 & 2.61 \\
Methyl butyrate & 1.69 & 1.74 \\
Methyl hexanoate & 0.31 & 0.30
\end{tabular}

The fatty acids obtained from the cream separator and cold methods had a similar profile. Overall, the fatty acids produced from the two methods were dominated by lauric acid (methyl lauric) at $48.64 \%$ for the cream separator method and $47.90 \%$ for the cold method (Table 3). In another study C12 (lauric acid) was found to be approximately 46.8948.03 (Marina et al., 2009) and 47.63-52.55 (Dia et al., 2005). These findings indicate that most coconut cream contains

(Pehowich et al, 2000).the addition of 3\% and 5\% sago starch could play a role in maintaining the stability of the paste.

\section{Creaming index of coconut cream}

Based on Table 4, the coconut cream paste without sago starch experienced a decrease in its stability since the first day of storage, which was indicated with high creaming index, either in the separator cream method or cold method. It showed that short-chain fatty acids, which are easily absorbed by the body the addition of $3 \%$ and $5 \%$ sago starch could play a role in maintaining the stabilitv of the paste.

Table 4 Creaming index of coconut cream paste.

\begin{tabular}{lc}
\hline \multicolumn{1}{c}{ Treatment } & Creaming index (\%) \\
\hline $\begin{array}{l}\text { Coconut Cream } \\
\text { Cream separator }\end{array}$ & 77 \\
\hline Without sago starch & 0 \\
\hline $3 \%$ of sago starch & 0 \\
\hline $5 \%$ of sago starch & \\
\hline Coconut Cream & 75 \\
Cold Storage & 0 \\
\hline Without sago starch & 0 \\
\hline $3 \%$ of sago starch & \\
\hline $5 \%$ of sago starch & \\
\hline Values are expressed as $\%$ of the paste height
\end{tabular}

In this study, starch and surfactants were added to coconut a role in increasing the viscosity of coconut cream during cream before homogenization. It can facilitate the process of homogenization to inhibit droplet coalescence, and creaming droplet cloaking during homogenization, as described by can be avoided. Tangsuphoom and Coupland (2009). In addition, starch plays 


\section{The appearance of coconut cream}

\section{Coconut cream separator}

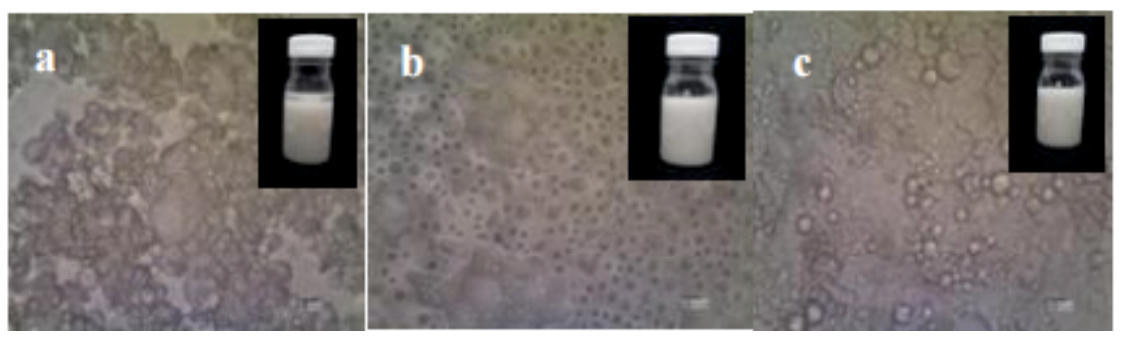

Coconut cream cold storage

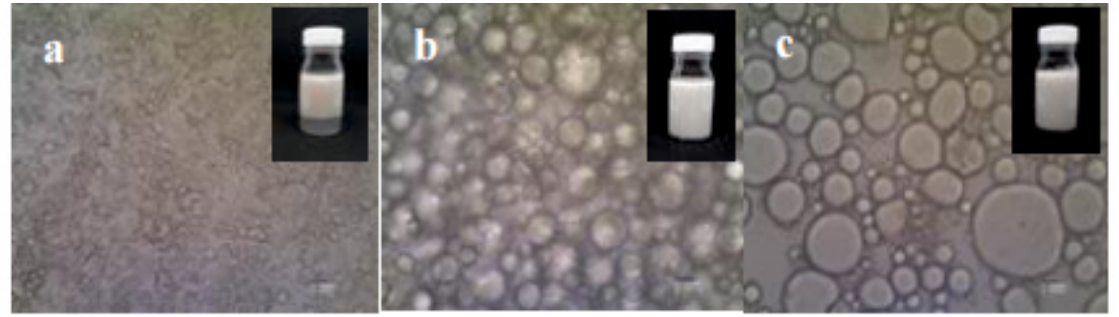

Figure 1 Optical appearance of the coconut cream paste (magnification 1000x with Optilab Microscope). a). without sago starch; b) 3\% sago starch; c) 5\% sago starch. inset: the visual appearance of the coconut cream paste on day-1. Scale bar: 100 $\mu \mathrm{m}$.

Figure 1 showed that the addition of sago starch was able to prevent the breakdown of the coconut cream paste. It could be seen from the appearance of round and uniform oil globules. In addition, sago starch also plays a role in maintaining the paste's physical stability, which can be seen from its milky white color. These findings indicate that the white coconut cream paste contains intact and uniform oil globules. A similar finding was reported by Li et al. (2013), who studied the stability of rice starch-based emulsions.

\section{Lightness, $\mathrm{pH}$ and viscosity of the coconut cream paste}

Table 5 shows the coconut cream paste's physical properties observed from the parameters of viscosity, lightness, and $\mathrm{pH}$. Overall, the addition of $3 \%$ and $5 \%$ sago starch to a cream separator and cold method increased the $\mathrm{pH}(4.60-4.70)$ and viscosity (3432-4265 cPs) of the paste compared to without the addition of sago starch $(\mathrm{p}<0.05)$, the results differed from those reported by Gonzalez (1990) and Tangsuphoom and Coupland (2008) who found that the $\mathrm{pH}$ and viscosity of coconut milk respectively were 5.95-6.30 and 1.61-2.02 cPs. The difference is due to the addition of sago starch in this study. It might be related to the character of sago starch, which tends to be neutral and viscous, thereby increasing the $\mathrm{pH}$ and viscosity of the coconut cream paste.

Table 5 Physical properties of coconut cream paste

\begin{tabular}{llll}
\hline Treatment & Lightness & $\mathrm{pH}$ & Viscosity $(\mathrm{cPs})$ \\
\hline Coconut Cream Cream separator & & \\
Without sago starch & $70.62 \pm 0.46^{\mathrm{c}}$ & $4.29 \pm 0.19^{\mathrm{b}}$ & $2532.33 \pm 57.73^{\mathrm{b}}$ \\
$3 \%$ of sago starch & $67.49 \pm 0.38^{\mathrm{a}}$ & $4.74 \pm 0.27^{\mathrm{b}}$ & $3432.33 \pm 57.73^{\mathrm{c}}$ \\
$5 \%$ of sago starch & $68.75 \pm 0.19^{\mathrm{b}}$ & $4.64 \pm 0.05^{\mathrm{c}}$ & $3565.67 \pm 208.16^{\mathrm{c}}$ \\
Coconut Cream Cold Storage & & \\
Without sago starch & $72.00 \pm 0.57^{\mathrm{a}}$ & $4.15 \pm 0.02^{\mathrm{b}}$ & $1733.33 \pm 115.47^{\mathrm{a}}$ \\
$3 \%$ of sago starch & $78.69 \pm 0.19^{\mathrm{c}}$ & $4.69 \pm 0.00^{\mathrm{c}}$ & $3799.00 \pm 0.00^{\mathrm{c}}$ \\
$5 \%$ of sago starch & $77.17 \pm 0.11^{\mathrm{b}}$ & $4.64 \pm 0.01^{\mathrm{c}}$ & $4265.67 \pm 57.73^{\mathrm{c}}$ \\
\hline
\end{tabular}

Different superscript letters in one column indicate a significantly different treatment $(\mathrm{p}<0.05)$

On the other hand, there were contradictory results on the lightness parameter. Sago starch decreased the lightness of the paste (cream separator method) and increased the lightness of the paste (cold method) (Table 5). A decrease in lightness was likely caused by prooxidants such as $\mathrm{Fe}$ in the cream separator tool to oxidize coconut cream and produce brown compounds. Besides, the addition of sago starch could decrease the lightness of the paste due to the browning phenomenon through a reaction between strach and Latent Polyphenol Oxidase (LPPO) (Onsa et al., 2000). 
Globular properties of coconut cream paste

Table 6 shows that the coconut cream paste without added sago starch underwent phase separation related to the optical micrograph of coconut cream Figure 1 and the globule size and zeta potential could not be evaluated. Meanwhile, the size of the paste globules added with 3\% sago starch had the most considerable zeta potential $(-30.5 \mathrm{mV})$ and the largest globule size $(44.08 \mu \mathrm{m})$. The value of $-30.5 \mathrm{mV}$ indicates high globular stability (Kislukhin et al., 2016; Singh et al., 2017). This finding was possible because the added sago starch was sufficient to influence the charge properties of the nanoparticles formed (Vaughn and Williams, 2007). Singh et al (2003) explained that starch contains phosphate, which was negatively charged.

Overall, it could be said that the globule size of the paste derived from the cream separator method and the addition of sago starch (3\% and 5\%) was more significant than the cold method. Kale and Deore (2017) explained that the globule size of 18-44 $\mu \mathrm{m}$ was included in the emulsion category. Table 6 showed that adding sago starch $3 \%$ with a cream separator can produce coconut cream paste containing a large and stable droplet size indicated by globula size $(44.08 \mu \mathrm{m})$ and zeta potential $(-30.50 \mathrm{mV})$ that is larger than other treatments.

Table 6. Average size and zeta potential of oil globules in coconut cream paste using Dynamic Light Scattering Method

\begin{tabular}{lcc}
\hline \multicolumn{1}{c}{ Treatment } & Mean size $(\mu \mathrm{m})$ & Zeta potential $(\mathrm{mV})$ \\
\hline \multicolumn{2}{l}{ Coconut cream cream separator } & N/A \\
Without sago starch & N/A & -30.50 \\
$3 \%$ of sago starch & $44.08 \pm 6.12^{\mathrm{a}}$ & -5.90 \\
$5 \%$ of sago starch & $31.94 \pm 4.07^{\mathrm{ab}}$ & \\
Coconut cream cold storage & N/A \\
Without sago starch & N/A & -19.50 \\
$3 \%$ of sago starch & $18.41 \pm 2.71^{\mathrm{c}}$ & -5.00 \\
$5 \%$ of sago starch & $24.77 \pm 5.14 \mathrm{~b}$ & \\
\hline
\end{tabular}

\section{Free fatty acids content from the coconut cream paste}

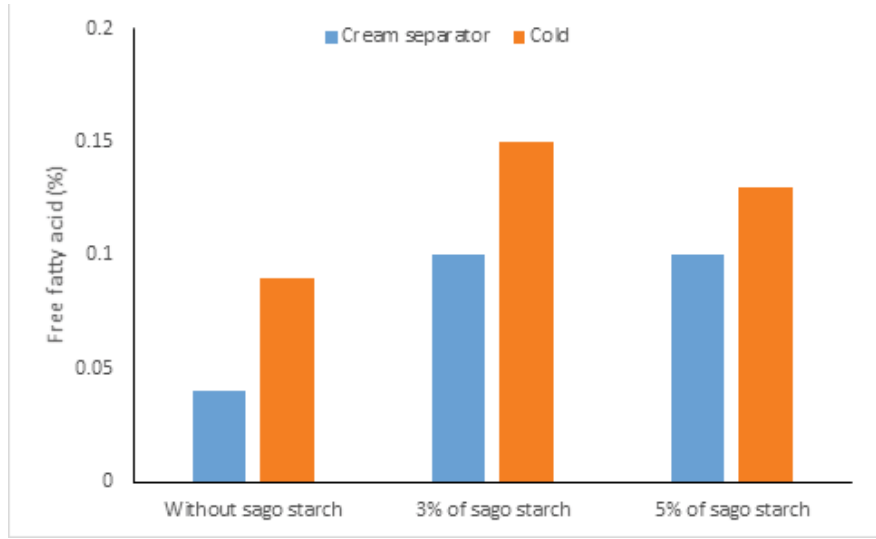

Figure 2. Free fatty acids from the coconut cream paste.

Figure 2 shows that the free fatty acid content of coconut cream paste was $<0.2 \%$ indicating that the coconut cream paste had met the minimum standard set by Indonesian Agency requirements (Indonesian National Standard, 2008). Coconut cream paste derived from the cold method has higher free fatty acids than the cream separator. This result has happened because the coconut cream produced by the cold method contained high moisture so it was easy to undergo hydrolysis (Sukasih et al, 2009) and might also experience oxidation through the presence of oxygen (Santoso, 2016).

\section{Coconut Cream Paste and Rendang Seasoning}

This study compared rendang seasoning mixed with coconut cream paste with commercial rendang seasoning. Overall, the sample's viscosity, lightness, and $\mathrm{pH}$ values in the samples were significantly different from commercial rendang seasoning $(p<0.05)$. The commercial rendang seasoning had much higher viscosity than the sample (Table 7). 
Table 7. Characteristics of coconut cream paste and rendang seasoning

\begin{tabular}{ccc}
\hline Parameter & $\begin{array}{c}\text { The rendang seasoning- } \\
\text { coconut cream paste } \\
\text { mixture }\end{array}$ & $\begin{array}{c}\text { The commercial rendang } \\
\text { seasoning }\end{array}$ \\
\hline Viscosity & $693.23 \pm 11.54^{\mathrm{a}}$ & $309336.33 \pm 41198.70^{\mathrm{b}}$ \\
Lightness & $32.51 \pm 0.14^{\mathrm{a}}$ & $20.21 \pm 0.01^{\mathrm{b}}$ \\
pH & $4.41 \pm 0.07^{\mathrm{a}}$ & $4.18 \pm 0.01^{\mathrm{b}}$ \\
\hline
\end{tabular}

Superscript letters that differ in a row indicate a significantly different treatment $(\mathrm{p}<0.05)$

Meanwhile, the sample's lightness and $\mathrm{pH}$ were higher than the commercial rendang seasoning (Table 7). The high viscosity and lightness of the sample was attributed with the addition of coconut cream paste. This finding indicates that coconut cream paste could improve the properties of rendang seasoning. The application of light and viscous pasta seasoning products has the potential to be expanded the food industry.

\section{CONCLUSION}

This study used the method of squeezing coconut flesh to obtain coconut milk. The two methods, namely the separator cream and the cold method, were performed to extract the coconut cream. The pasta product was made by adding $3 \%$ and $5 \%$ sago starch and surfactant to increase the stability of the coconut cream. The findings showed that the separator cream method with the addition of 3\% sago starch and surfactant was able to produce a better-quality paste with low free fatty acids $(0.1 \%)$ and high zeta potential $(-30.5 \mathrm{mV})$ compared to the cold method. Finally, the coconut cream paste can be used as a mixture of rendang seasoning with a higher lightness (32.5) and lower viscosity (693.23 cPs) than commercial rendang seasoning. Therefore, the cream separator method with the addition of sago starch and surfactant is potent to be used to produce coconut cream paste, which is suitable as an ingredient of rendang seasoning.

\section{ACKNOWLEDGMENT}

The authors would like to thank the research funding assistance from the UGM CaRED program in collaboration with the Ministry of Foreign Affairs and Trade (MFAT) New Zealand

\section{REFERENCES}

Aboulfazli, F., Amal, B. and Ahmad, S. 2016. "Effects of the Replacement of Cow Milk with Vegetable Milk on Probiotics and Nutritional profile of Fermented Ice Cream." LWT - Food Science and $\begin{array}{lrr}\mathrm{T} \text { e c h n o } 10 \mathrm{~g} \mathrm{y} & 70: & 261-270\end{array}$ http://dx.doi.org/10.1016/j.lwt.2016.02.056.

Anonymous. 2005. Official Methods of Analysis of AOAC International, $18^{\text {th }}$ Ed. $\quad 33.2 .43(\operatorname{method} 990.19), 33.3 .19(\operatorname{method} 995.19)$, 33.2.27 (AOAC 989.04), 33.2.27A (method 989.05), 33.2.31 (AOAC 972.16). Association of Official Analytical Chemists. AOAC International, Maryland, USA..

Aparecida, I., Eliana, P. and Antonia, M. 2011. "Evaluation of Green Coconut (Cocos nucifera L.) Pulp for Use as Milk, Fat and Emulsifier Replacer in Ice Cream." Italian Oral Surgery 1. E $1 \mathrm{~s}$ e vi e r $\quad$ S r 1: $1447-1453$ https://doi.org/10.1016/j.profoo.2011.09.214.

Arachchi, L. L. A. C. N., Gunathilake, K. D. P. P. and Prasadi, V. P. N. 2016. Shelf Life and Quality Evaluation of Deep Frozen Coconut Cream, Coconut Scrapings and Coconut Slices. Cord 32:34-39

Ariyaprakai, S., Limpachoti, T. and Pradipasena, P. 2013. Interfacial and emulsifying properties of sucrose ester in coconut milk emulsions in comparasion with Tween. Food Hydrocolloids 30 $\left(\begin{array}{llll}2 & 0 & 1 & 3\end{array}\right)$ : http://dx.doi.org/10.1016/j.foodhyd.2012.06.003

Azima, F. and Kesuma, S. 2016. The Evaluation of Nutritional Value of Rendang Minangkabau. Agriculture and Agricultural Science P r o c e dia 9. E $1 \mathrm{~s}$ e vi e r S r 1: $335-341$. https://doi.org/10.1016/j.aaspro.2016.02.146.
Cable News Network. 2017 . C N T Travel Staff https://edition.cnn.com/travel/article/world-best-fooddishes/index.html

Charoenkul, K. and Darinee, P. 2017. Development and Characterization of Nano - Cream Preparation Containing Natural Extract Using Nanoemulsion Techniques. Materials Today: Proceedings 4 (5).

E $1 \mathrm{~s}$ e $\mathrm{v}$ i e $\mathrm{L} \mathrm{t} d: 6105-6110$ https://doi.org/10.1016/j.matpr.2017.06.101.

Dia, V. P., Garcia, V. V., Mabesa, R. C. and Tecson-Mendoza, E. M. 2005. Comparative physicochemical characteristics of virgin coconut oil produced by different methods. Philippine Agricultural Science 88: 462-475.

Divya, V., Baskaran, D. and Gnanalaksshmi, K. S. 2017. Standardization of Optimal Level of Coconut Variants in Chocolates Based on Consumer Acceptance. Current Research in Nutrition and Food Science $5(1): 36-42$.

Gonzalez, O. N. 1990. Coconut milk, coconut-based beverages, coconut proteins, in Banzon, J. A., Gonzalez, O. N., Leon, S. Y. de and Sanchez, P. C. Coconut as Food. PCRDF. Quenzon City. Mexico.

Gubag, R. 1996. Sapal : A Traditional Fermented Taro [Colocasia esculenta ( L .) Schott $]$ Corrm and Coconut Cream Mixture from Papua New Guinea. International Journal of Food Microbiology 28: 361-367.

Hagenmaier, R. 1980. Coconut Aqueous Processing. San Carlos Publication, Cebu City, Philippines. pp: 213

Igutti, A. M., Ana, C. I., Pereira, L. F., Silva, R. A. F. and Ribeiro, P. 2011 Substitution of Ingredients by Green Coconut (Cocos nucifera $L)$ Pulp in Ice Cream Formulation. Procedia Food Science (1): 1610-1617. https://doi.org/10.1016/j.profoo.2011.09.238.

Indonesian National Standart. 2008. SN 7381: 2008. Minyak Kelapa Virgin (VCO). Badan Standarisasi Nasional. Jakarta.

Jin, Y., Suna, K., Da, H., Yeo, J., Woo, R., Yoo, M. and Sunmin, P. 2017. Calorie Reduction of Chocolate Ganache through Substitution of Whipped Cream. Journal of Ethnic Foods 4 (1). Elsevier Ltd: 51-57.

Kale, S. N. and Deore, L. S. 2017. Emulsion Micro Emulsion and Nano Emulsion : A Review. Sys Rev Pharm 8(1): 39-47.

Kislukhin, A. A., Xu, H., Adams, S. R.,Narsinh, K. H., Tsien, R.Y. and Ahrens, E. T. 2016. Paramagnet- ic fluorinated nanoemulsions for sensitive cellular fluorine-19 magnetic resonance imaging, Nat. Mater. 15: $662-668$.

Le, H. D. and Van., V. M. L. 2014. Application of Ultrasound to Microencapsulation of Coconut Milk Fat by Spray Drying Method. J. Food Sci Technol:1-5. DOI 10.1007/s13197-014-1285y.

Li. C., Li Y., Sun, P. and Yang, C. 2013. Pickering emulsion stabilized by native strach granules. Colloiids and surfaces A: Physcochem. Eng. Aspect. 431: 142-149.

Mangalika, U. L. P., Arora, S., Sharma, G. S., Mann, B. and Wadhwa, B. K. 2005. Proteolysis of coconut cream filled gouda cheese during ripening. Indian J Dairy Sci 58(3): 177-183.

Mangalika, U. L. P. 2004. Effect of Coconut Fat As Milk Fat Replacer On Physico-chemical Characteristics of Gouda Cheese. Thesis: Deemed University, India.

Marina, A. M., Che Man, Y. B., Nazimah, S. A. H. and Amin, I. 2009. Chemical properties of virgin coconut oil. Journal of the American Oil Chemists' Society 86: 301-307.

Martinez, M. M., Li, C., Okoniewska, M., Mukherjee, I., Vellucci, D. and Hamaker, B. 2018. Slowly digestible starch in fully gelatinized material is structurally driven by molecular size and A and B1 chain lengths. Carbohydrate Polymers, 197: 531-539. 
McClements, D. J. and Gumus, C. E. 2016. Natural emulsifiersBiosurfactans, phospholipids, biopolymers, and colloida particles: Molecular and physicochemical basis of functional performance. Advances in Colloid and Interface Science 234 (6): 3-26. DOI:10.1016/j.cis.2016.03.002

Nurmufida, M., Gervasius, H., Wangrimen, R. R. and Kevin, L. 2017. Rendang: The Treasure of Minangkabau. Journal of Ethnic Foods 4: 232-235. https://doi.org/10/1016/j.jef.2017.10.005

Onsa, G. H., Saari, N., Selamat, J. and Bakar, J. 2000. Latent Pholyphenol Oxidases from Sago Log (Metroxylon sagu): Partial Purification, Activation, and Some Properties. Journal of Agricultural and Food Chemistry, 48 (10): 5041-5045.

Pehowich, D. J., Gomes A. V. and Barnes, J. A. 2000. Fatty Acid Composition and Possible Health Effect of Coconut Constituents. West Indian Med J 2000; 49 (2): 128.

Santoso, U. 2016. Antioksidan Pangan. Yogyakarta: Gadjah Mada University Press.

Sasikala, S. and Hasker, E. 2013. Coconut : An Extensive Review on Value Added Products TARs. 32 (6):

Shan, H., Grace, T., Bin, Y., Philip, C. and Shao, Q. 2011. Lipase Catalysed Synthesis of Natural Aroma-Active 2-Phenylethyl Esters in Coconut Cream. Food Chemistry 124 (1). Elsevier Ltd:80-84. https://doi.org/10.1016/j.foodchem.2010.05.108.

Singh, N., Singh, J., Kaur, L., Singh Sodhi, N., Singh Gill, B. 2003. Morphological, thermal and rheological properties of straches from different botanical sources. Food Chemistry (81): 219-231.

Singh, Y., Meher, J. G., Raval, K., Khan, F. A., Chaurasia, M. Jain, N. K. and Chourasia, M. K. 2017. Nanoemulsion: Concepts, development and applications in drug delivery. Journal of Controlled Release $252: 28-49$.

Stryer, L. 1975. Biochemistry. San Francisco: W. H. Freeman and Company: 877.

Sukasih, E., Prabawati, S. and Hidayat, T. 2009. Optimasi Kecukupan Panas Pada Pasteurisasi Santan dan Pengaruhnya Terhadap Mutu Santan Yang Dihasilkan". J. Pascapanen 6(1): 34-42.

Sun, J., Bin, Y., Philip, C. and Shao-quan, L. 2012 . Optimisation of Flavour Ester Biosynthesis in an Aqueous System of Coconut Cream and Fusel Oil Catalysed by Lipase. Food Chemistry 135 (4): $\quad 2714-2720$. https://doi.org/10.1016/i.foodchem.2012.06.119.

Tangsuphoom, N. and Coupland, J. N. 2008. Effect of pH and Ionic Strength on the Psycochemical Properties of Coconut Milk Emulsion. Journal of Food Science $73 \quad(6): \quad 274-280$. https://doi.org/10.1111/j.1750-3841.2008.00819.

Tangsuphoom, N. and Coupland, J. N. 2009. Effect of surface-active stabilizers on the microstructure and stability of coconut milk emulsions. Food Hydrocolloids 22: 1233-1342

Vaughn, J. M. and Williams, R. O. 2007. Nanoparticle Engineering. In Swarbrick. James. Encyclopedia of Pharmaceutical Technology Third Edition. Volume 1. New York: Nova Science Publisher, 48.

Wihenti, A. I. 2020. Physical and Chemical Characteristics of Corn Husk as Packaging Material. Theses: Gadjah Mada University, Indonesia.

Yamaguchi, S. and Ninomiya, K. 2000. The Use and Utility of Glutamate as Flavoring Agents in Food. American Society for Nutrition Sciences. Journal Nutrition 130:921-926.

Yin, C., Abdul, W., Law, Y. and Jamaliah, J. 2015. Sequential Fractionation of Value-Added Coconut Products Using Membrane Processes. Journal of Industrial and Engineering Chemistry 25. The Korean Society of Industrial and Engineering Chemistry:162-67. https://doi.org/10.1016/j.jiec.2014.10.028. 